\title{
The costs of customs compliance in Croatia in 2001
}

\section{Bronić, Mihaela}

Source / Izvornik: Occasional Paper Series, 2004, 8, 1 - 28

Journal article, Published version

Rad u časopisu, Objavljena verzija rada (izdavačev PDF)

https://doi.org/10.3326/ops.21

Permanent link / Trajna poveznica: https://urn.nsk.hr/urn:nbn:hr:242:503536

Rights / Prava: Attribution-NonCommercial-NoDerivatives 4.0 International/ImenovanjeNekomercijalno-Bez prerada 4.0 međunarodna

Download date / Datum preuzimanja: 2023-04-26

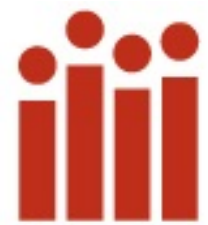

Repository / Repozitorij:

Institute of Public Finance Repository

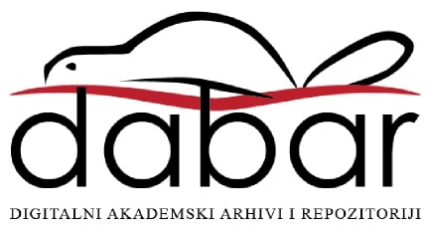




\section{THE COSTS OF CUSTOMS COMPLIANCE IN CROATIA IN 2001}

Mihaela Bronić

Occasional Paper No. 21

November 2004 


\title{
THE COSTS OF CUSTOMS COMPLIANCE IN CROATIA IN 2001
}

\author{
Mihaela Bronić \\ Institute of Public Finance, Zagreb \\ mihaela@ijf.hr
}

\section{Abstract}

The purpose of the paper is to show the size and the basic characteristics of customs compliance costs of importers (legal entities and small business) in the Republic of Croatia in 2001. The customs compliance costs comprise those costs that the customs payers incur in order to meet the provisions of the customs laws and the requests of the customs administration. Only the amount of the customs duty paid and any distortion costs arising from paying customs duty are not customs compliance costs.

The research was carried out by the face-to-face interview method, in the period from June to October 2002. It was concluded that the Croatian customs compliance costs in 2001 were regressive. It was also concluded that costs were large in comparison with the total customs revenue and GDP. It is estimated that customs compliance costs for importers (legal entities and small businesses) in RC in 2001 were around 1,006 million HRK. That is $0.6 \%$ GNP and around $31 \%$ of total Croatian customs revenues in 2001.

There is not, unfortunately, a single foreign research of the costs of customs compliance that could be used as a comparison. What is more the research faced many problems (e,g. non-representative and small samples) so one should be cautious when using its results. For this reason we would conclude that the primary purpose of this research is to pose relevant questions related to the conceptual and methodological problems of customs compliance cost research. Furthermore it should indicate possible size and characteristics of the customs compliance costs in the RC.

JEL Classification: E62, H20

Key words: customs compliance costs, Croatia, regressiveness

\footnotetext{
${ }^{1}$ This research was supported by a grant from the CERGE-EI Foundation under a program of the Global Development Network. Additional funds for grantees in the Balkan countries have been provided by the Austrian Government through WIIW, Vienna. All opinions expressed are those of the author and have not been endorsed by CERGE-EI, WIIW, or the GDN. Additional funds were also given by the Institute of Public Finance, Zagreb, the institution that led the project: "Costs of Taxation in Croatia: Administrative Costs and the Costs of Tax Compliance", of which this paper is a part. The questionnaires were carried out and in line with instructions statistically processed in PULS d.o.o., Agency for Market, Media and Public Opinion Research - below, PULS. The PULS then is responsible for the processing of the data; the author is responsible for everything else.

The author would like to thank the leaders of the project, in particularly Helena Blažić from the Economics Faculty, Rijeka, Katarina Ott and Ivica Urban from the Institute for Public Finance, employees of the Customs Administration, particularly Oskar Cukrov and Ivana Soić, certain agents, employees of the PULS, the reviewers and all those who have helped in the composition, analysis and writing of this paper. This article is published in Croatian in the journal "Carinski vjesnik", 13(1), 2004, pp. 3-32.
} 


\section{Introduction}

The purpose of the paper is to indicate the size and basic characteristics of customs compliance costs (CCC) for importers (legal entities and small businesses) in the Republic of Croatia (RC) for 2001.

After the introduction in the second part of this paper the concept of customs compliance will be defined in greater detail. The third part of the work expounds knowledge obtained to date about the CCC, and the reasons for which they should be investigated. The fourth part of the work lists the basic hypotheses of the study.

Part five considers the methodological and conceptual problems of the elaboration of the questionnaire according to which the interviewing was done.

Part six explains the customs compliance costs investigative method - the face to face interview. The problems faced by the pollsters of the questionnaire will be listed too.

The results of the research are shown in part seven. Finally come recommendations for a reduction of the CCC and a conclusion.

\section{Definition of the costs of customs compliance}

There are various classifications of the costs that incurred in a society as a consequence of collecting taxes. ${ }^{2}$ Most authors agree that these costs can be divided into costs to the tax administration (administrative costs) and costs to the taxpayer (compliance costs) (Sanford et. al., 1989; Haughton, 1998; Sanford, 2000).

Administrative costs are all public sector costs incurred during the administration of the existing tax laws. These, then, may be defined as the costs of passing and implementing the tax laws, including any proposals for changes in them (Sanford et. al., 1989). They contain expenditures of the government institutions that deal with the administration of taxes. ${ }^{3}$

Compliance costs comprise those costs that the taxpayers incur in order to meet the provisions of the tax laws and the requests of the tax administration. The costs of the taxpayer are all those costs that the taxpayer has to bear on top of the actual taxes (Kesner-Škreb, 1999; Sanford et. al., 1989; Allers, 1994; Sanford, 2000).

In this paper customs duties, one of the oldest forms of taxation, are studied. ${ }^{4}$ There is very little literature concerning the customs compliance costs (CCC), hence for a more detailed definition of them works concerning tax compliance, particularly VAT, (mainly Sanford et. al., 1989; Klun, 2002; Allers, 1994) have been used.

\footnotetext{
${ }^{2}$ Apart from the costs of collecting taxes (administrative and compliance costs) there are two other types of costs incurred in society because of the introduction of taxes. Firstly there is the efficiency cost to the economy because taxes change the behaviour of taxpayer. Secondly there is taxpayer cost related to the loss of part of his/her purchasing power due to paid taxes (Ott and Bajo, 2000).

${ }^{3}$ For more about the administrative costs of taxation in transitional countries and the RC see Ott and Bajo, 2000. Apart from this, as a part of this project called "Costs of Taxation in Croatia: The Administrative Costs and Compliance Costs of Taxation", Bratic and Pitarević (2003) deal with the administrative costs of taxation and customs in the RC, $1999-2001$.

${ }^{4}$ Customs duty is usually paid on goods that are imported. Customs duty, in the RC, is paid in line with the Customs Tariff Law, the Customs Law and a number of other provisions, laws, regulations, decisions and rulings (Kesner-Škreb and Kuliš, 2001).
} 
We define that CCC as costs that customs taxpayers or other persons (working for customs taxpayers) incur in order to meet the provisions of the customs laws and the requests of the customs administration. Only the amount of the customs duty paid and any distortion costs arising from paying customs duty are not CCC.

CCC could be classified in several ways. Firstly CCC could be classified according to type of customs payer. These could be legal entities, small businesses or natural persons. In this paper we are focusing on legal entities and small businesses. Out of the desire for as great simplicity as possible in the research, natural persons who were not small businesses were not interviewed. An additional argument was that a natural person should not have great CCC (except for time spent), particularly if the value of the dutiable goods is less than $5,000 \mathrm{HRK}^{5}$

Secondly CCC could be classified according to the customs procedure to which they are related. In $\mathrm{RC}$ there are 8 customs procedures:

- releasing goods for sale (import),

- export procedure,

- transit procedure,

- customs warehousing procedure,

- internal production procedure,

- processing under customs control procedure, and

- temporary import procedure and foreign production procedure.

Although it is to be expected that $\mathrm{CCC}$ for each customs procedure are different, in this project it was impossible to investigate $\mathrm{CCC}$ for each customs procedure separately. Since the import procedure is most often a customs procedure in Croatia, the paper focuses on total CCC related to importers. ${ }^{6}$

Thirdly CCC can be classified into internal and external CCC. Internal CCC are costs emerged in the small business or in the legal entity, and external are CCC emerged outside the small business or in the legal entity. For example external CCC are costs of professional advisers (customs clearing agents) used for help with customs compliance.

Internal (in the small business or in the legal entity) CCC can be divided into:

1. internal labour costs (salaries, wages and etc.) related to customs compliance,

2. other internal costs not related to labour costs (such as additional software and hardware used for complying with customs, the cost of telephone and personal consultations with officials of the Customs Administration and customs advisers... $)^{7}$

\footnotetext{
${ }^{5}$ For imported goods worth up to $300 \mathrm{HRK}$ per person customs duties are not paid. For imported goods worth from 300 to 5000 HRK per person customs duty is paid at flat rate $(10 \%)$. For more on the financial costs of natural persons on the customs border, see Buršić et al, 2002.

${ }^{6}$ Of course it is to be expected that some of the importers are not only importing but also perform other customs procedures (e.g. export). Thus since it was hard for interviewed importers to separate CCC for each of the customs procedures they perform the paper analyses CCC for all the customs procedures of the interviewed importers in 2001.

Only costs used for complying with customs should be considered here, and not the cost which would exist even if the customs duties did not exist. This is in reality really hard to accomplish, because the accounting records are not so sophisticated. That is the costs of customs compliance do not exist as a separate accounting category, but rather employees have to estimate them from the total costs. For example employees have to estimate how many computers have been used for customs compliance and how much the amortization of those computers is.
} 
3. psychological costs. These are mostly internal CCC and they can be defined as concern, anxiety or unrest caused by complying with customs duties. It is extremely hard to measure them, but this paper tries to do that.

It should be stated that in 2000 a new Customs Law came, into force. The basic features of this law as against its predecessors are: liberalisation of the customs procedure, accelerated customs formalities, the creation of the preconditions for the reduction of import customs duties and the reduction of the number of exemptions and privileges. In addition, on 30 November 2000 Croatia became a full member of the WTO. Entry into the WTO led to the reduction of high protective tariffs as well as nontariff barriers to trade (Galinec and Jurlin, 2002).

It was important to mention the coming into force of the new Customs Law and the entry into the WTO, for these changes, however much they should in the long-run lead to a reduction in the CCC, most likely in 2001 resulted in their increase (because of the importers' need to adjust to the new regulations). Hence it is possible that in 2001 the CCC were somewhat greater than in other years when there were no such major changes in the customs system.

\section{What is known about the costs of customs compliance and why we have investigated them?}

In the literature there are few papers devoted to the CCC. Even direct contact with several of the most highly developed tax administrations (the USA, Canada, Australia and the UK) was not of very great use in finding out more about these costs.

What is, nevertheless, known about these costs? In the mid-1980s, the European Commission carried out research using a sample of 500 companies in six member countries, examining the total costs of tax and customs compliance costs and the costs of statistical reporting connected to trade among the EU countries.

In the Cecchini Report, as it was called, it was estimated that the total costs that are borne by legal entities (because of taxes, customs and statistical reporting relating to the trade among the countries of the EU) came in 1986 to about $2 \%$ of the value of total trade among EU countries. But this research has not been of much use to us because the results of it were much criticised (see Verwaal and Cnossen, 2002). An additional reason is that this research relates to CCC, as well as compliance with certain other taxes and the costs of statistical reporting at borders, which is much broader than the CCC, the subject of this study.

Apart from this, the World Customs Organisation (WCO, 2003) reports that some studies estimate that formalities at borders accompanying custom compliance result in costs of $7-10 \%$ of the value of a given dutiable consignment. However, this research too was of little use to us, because it is impossible to conclude clearly from it what these costs are, which border formalities are referred to, how the research was carried out, and so on. 
However, irrespective of all these restrictions, from both the researches it is clear that the CCC do exist and that they are considerable. What is more CCC lead to a reduction in international trade (Verwaal and Donkers, 2001). Hence their negative effect on the size of international trade is one of the reasons for them to be investigated.

There are other reasons why CCC should be investigated. Thus authors like Haughton (1998) and Sanford (2000) state that many researches in tax compliance costs have shown that the costs to the taxpayer are several times greater than costs of the tax administration for the collection of given taxes. Hence, apart from it being important for us to investigate how much the Customs Administration spent in a given year (administrative costs) ${ }^{8}$ it is also important to determine what the CCC (the costs of the customs payer) were. Finally we wanted to make recommendations to the Customs Administration and customs taxpayers concerning ways of reducing existing CCC in the Republic of Croatia. ${ }^{9}$

\section{The objective of the research}

As said the objective of the research is to determine the magnitude and basic characteristics of the CCC in the RC in 2001 for importers (small businesses and legal entities).

The basic hypothesis of this work is that the CCC in the RC are regressive. Meaning that a $1 \%$ rise in the value of imports brings about a growth of the CCC of less than $1 \%$. For this reason as the value of imports rises, CCC per unit falls. Thus regressiveness then means that the $\mathrm{CCC}$ fall disproportionately more heavily on smaller importers. The reason for this is a certain fixed component in the CCC, which stays the same irrespective of the value of the import. For example the costs of the literature used for customs compliance or seminars attended is probably the same no matter how much one imports.

Then, the second hypothesis of the work is that the total CCC are absolutely and relatively large (in relation to GDP and to total customs revenue for 2001).

Apart from the basic hypotheses, the following are also tested:

- CCC is very hard to identify and measure because the methods of measuring CCC are mostly unreliable. The methods are based on the opinions of interviewed persons,

- the interviewing done by pollsters is not as useful as that performed by CCC researchers,

- the CCC have gone down in the last five years.

We also wanted to reveal any areas in which it might be possible to reduce the CCC. For this reason there was an attempt to evaluate the benefits from submitting the Single Administrative Document $(S A D)^{10}$ on-line, and the benefit from the use of simplified customs procedures. Apart from that, an attempt was made to evaluate the psychological component of the $\mathrm{CCC}$ and the degree of satisfaction of importers with the work of the Customs Administration (CA).

\footnotetext{
${ }^{8}$ Bratić and Pitarević (2003) estimate that total administrative costs of the Customs Administration in 2001 came to 300 million HRK.

${ }_{9}^{9}$ For other reasons why compliance costs should be investigated see Sanford (2000).

${ }^{10}$ The SAD is the basic customs document that is submitted when customs clearing is sought for goods. There are 8 customs procedures (releasing goods for sale (import), export procedure, transit procedure, customs warehousing procedure, internal production procedure, processing under customs control procedure, temporary import procedure and foreign production procedure). For all these customs procedures, a SAD is submitted.
} 


\section{Methodological explanations}

The research was carried out with the use of face-to-face interviews, in the period from June to October 2002. Seventeen small businesses and 50 legal entities, importers, were interviewed (Annex 1).

As already mentioned, in the research, we came upon a series of conceptual and methodological problems. Now the most important ones will be explained.

\subsection{Basic problems}

The most important problems in drawing up the questionnaire were: first, whom to interview? Who would best be able to estimate what the CCC were? Most of the legal entities and small businesses used agents (customs clearing agents) ${ }^{11}$ for customs compliance. Legal entities and small businesses can do the importing themselves, but because of their lack of knowledge of procedures, the hiring of customs clearing agents (below: agents) is a regular procedure.

Furthermore from agents we obtained the information that many agents send invoices to the importers for whom they carry out customs matters in which there is no specification of how much money is paid for the CCC, and how much for any other costs, such as the transportation of goods, loading and unloading and so on. Since costs related to jobs such as transport, loading, unloading and so on are not reckoned the CCC, we decided, with a series of control questions, to ask agents about the magnitude of the CCC, and about the problems that they meet in customs compliance.

But then the question arose about what to do if an importer in 2001 used several agents. Were we to interview one or several or all of his agents? For the sake of simplicity, we decided to interview only one agent, the one through which the importer imported the most goods, in terms of dutiable value of goods, in 2001.

One has to mention another reason for which it was difficult to estimate what the CCC were. Although it is stated everywhere that the $\mathrm{CCC}$ relate only to those costs that incurred to provide compliance with the customs laws and the requirements of the Customs Administration, in practice importers, during import, pay excise and VAT at the same time. As already mentioned there are no detailed accounting data for CCC and the interviewed persons have to estimate how much of the costs are for CCC. For this reason it is possible that the CCC have been exaggerated in the research, that is, that the interviewed persons alongside the CCC included some of the costs that relate to VAT and excise compliance on importation.

The project faced the dilemma: what should the questionnaire and the questions look like to be understandable? It was impossible to rely on other research, or use the findings from the literature or other research. Hence in writing the questionnaire used to carry out the interview, we were helped by several employees of the CA and agents. The employee of PULS was supposed to enable the questions to be clear and intelligible to the interviewees. The wish was to make a questionnaire that would have as few as possible open-ended questions. However, since this is one of the first

\footnotetext{
${ }^{11}$ Agents or forwarders are companies or sole traders that carry out customs procedures for third parties.
} 
researches in the area of the CCC and it was wished to test out many different hypotheses, the questionnaire turned out actually to be quite long and complicated. In future researches fewer hypotheses should be tested in a single project and the questionnaires should be as simple as possible.

The monetary evaluation of time spent on customs compliance represented an additional problem. In other research various values have been used for the monetary evaluation of time spent for compliance with various tax liabilities. Klun (2002) gives a very good survey of the values so far used in the monetary evaluation of the time of employees spent in VAT compliance ${ }^{12}$. Because there is no single right solution, and that every measurement has its drawback, whenever possible, the research of the monetary evaluation of the time spent was conducted like that of Allers (1994), with the aid of natural indicators (the gross cost (wage) of an hour stated by the interviewees themselves). If the interviewees have stated the net wage rate, that rate was recalculated into gross wage rate ${ }^{13}$ with the employer's social security contributions added in order to get to the full labour time costs.

The next problem is that in the past researches have shown that it is not enough to ask the interviewees only about the amounts spent on costs of compliance with a given tax, because people do not know what is implied by the concept of compliance costs. Even Sanford et. al., (1989:10) remark that the concept of "costs of tax compliance" is fairly fuzzy. Hence the CCC in the questionnaire are shown according to the customs activities they are linked with). ${ }^{14}$ For the same reason, in the accompanying letter that was given to the interviewees together with the questionnaire, there was yet another definition of what exactly CCC are.

\subsection{Sample characteristics}

The database of the Customs Administration for 2001 was used for the selection of the sample of interviewed importers. ${ }^{15}$ In that year there were the following importers: 18,422 legal, 50,567 natural entities and 6,497 natural entities registered for agricultural activities (small businesses).

By random selection from the database of all importers in the RC 75 legal entities and 25 small businesses were chosen. They were chosen depending on the value of their imports and the region where their headquarter was (Zagreb, Varaždin, Split and Velika Ves). The reason for the focus on these cities is that these are some of the towns in the counties that in 2000 had the greatest imports ${ }^{16}$ and in which PULS was able to carry out interviews.

\footnotetext{
${ }^{12}$ We mention VAT because customs duties are in their characteristics most similar to VAT.

${ }^{13}$ Using the standardized formula to convert net wages into gross wages, taking into account the town where interview was done (because of the local surtax rate). Tax allowance for only one dependent person (child) was assumed.

${ }^{14}$ These are the costs of all activities related to:

1. the costs of acquaintance of necessary knowledge for customs compliance (collection of information, keeping up with the customs law and trade literature, attending seminars),

2. the costs of processing, submitting and keeping different customs forms (eg. SAD),

3. the warehousing of goods for customs purposes,

4. the costs of all activities related to the customs guarantee,

5. the costs of all activities related to court costs and fines,

6 . the costs of agents and so on.

${ }^{15}$ Similarly, research into the costs of income tax compliance in the UK used the data base of the tax administration for the selection of a sample (Sanford et al., 1989).

${ }^{16}$ Detailed data about regional import in terms of cities were not available. We only have the size of imports for 2000 at the county level. Thus during 2000 most goods were imported by firms with HQs in Zagreb (54.3\% of all imports). The imports of
} 


\section{The method-face to face interview}

Sanford et. al., (1989) say that all the methods that are used for social research can be used in research of the costs of tax compliance. However, in practice, most of the costs of tax compliance have been investigated by postal questionnaires or by detailed in-depth time and motion studies. These two methods were most often backed up with interviews and telephone interviews.

This research used the method of face-to-face interview; the interview period lasted from June to October 2002. Although it is well known that interviews are more expensive than postal questionnaires, PULS suggested that interviews were very qualitative and reliable and that they would enable a faster completion of the project, and better control of samples and the polling process than postal questionnaires, and that the costs would not be so much greater than research carried out by postal questionnaires.

After drawing up the questionnaire, we consulted with several agents and a pilot project was carried out. After the implementation of the pilot project came the actual interviewing.

\subsection{Problems that surfaced during the interviews}

Some of the problems that we were faced with during the interviewing period had been remarked on by Sanford et. al., (1989). Pollsters are people who are not researchers and hence do not know the area under research very well. They do not have the time or the knowledge to be able to deal with interesting issues and matters that might come to light during the research. Apart from that, although the pollsters have to keep to a set of instructions and questions defined in advance, it can happen that they do not interpret some of the questions well, or that they define them in an inappropriate way, hence the interviews carried out by the pollsters can be less useful than those administered by the actual investigators. The recommendation is then that as many interviews as possible (if this is the research method) should be carried out by the researchers themselves, for in this way more interesting information will be acquired.

In addition, because of the demanding nature of the interviews, the project started with experienced pollsters, but they lost heart when they came upon the most various problems. For a completed whole questionnaire, a lot of effort was required. The biggest problem was that the data base about importers that the pollsters had at their disposal was not kept up to date. Some of the importers from the data base did not exist, while others had changed their business address, etc.

The pollsters on the whole met with respondents who did not have a lot of patience with giving all the data necessary, particularly concerned with questions that required checking up and finding data in documentation and reports. For example, it was not easy for interviewers to estimate which part of the overhead costs (electricity, water, heating, etc) related to customs matters. Furthermore, informants were not keen on questions connected with finances and wages. Many of them did not wish to reply, alleging "business confidentiality" remarking that "this would be an invasion of privacy".

other counties are diverse and fragmentary. The largest individual share in imports went to Istria County (6\% of all imports), then Primorsko-Goranska (5.7\%), Zagreb County (5\%), Split (4.6\%) and Varaždin (3.9\%) (Galinec, 2001). 
Questions related to an estimate of the time spent on individual jobs relating to customs compliance in the last twelve months made very great demands on the subjects. ${ }^{17}$ It was hard to estimate how much time all the employees had spent only on customs compliance and nothing else.

For this reason it was extremely difficult to find a happy medium between the investigative desire for as much as possible accurate data, and the unwillingness of the interviewees to put in the great amount of effort that was required from them in the filling out of this kind of questionnaire. Thus in the future if one wishes to carry out an research of a large population, it would be best to limit oneself to simpler and less demanding questions that the informants will find it easier to answer.

An additional problem is that for the questions asked, depending on the situation, it was necessary to contact three persons (the owner, the employee who deals with customs matters in a legal entity or small business, and the agents). Quite frequently occurred that first two parts of the questionnaire would be successfully completed, and that to fill in the third part of the questionnaire it was necessary to wait for people from the agent, who did not want to take part, or had no time. Hence the recommendation, if possible, is to reduce the number of persons it is necessary to interview to fill out a questionnaire.

Interviewing also stretched on into the time of the annual vacations, which was an additional obstacle. At any rate, in the end the interviewing was concluded with a great deal of trouble in searching out reliable respondents who have the time and patience for this kind of research.

All these problems, and the fact that the interviews were nevertheless extremely expensive and had thus to be done on a much smaller scale resulted in a smaller number of persons being interviewed than had been planned. Of the planned 25, 17 small businesses were interviewed; of the planned 75 , only 50 legal entities made responses (Annex 1). Below follow the most basic results of the research for small businesses, and then more detailed results for the research relating to legal entities.

\section{The results of the research}

\subsection{The results of the research for small businesses}

Most of the economists who have investigated the costs of tax compliance abroad have come to the conclusion that the costs of tax compliance are regressive (Sanford et. al., 1989; Allers, 1994; Klun, 2002; Sanford, 2000).

Because of the problems with the interviewing, and the low number of persons interviewed, our small business sample turned out not to be representative, and there was no sense in testing anything but the most basic hypothesis in connection with it, that of regressiveness. ${ }^{18}$

It is logical that with the rise in the imports of a small business, its total CCC should also rise. For example, an importer will probably import more consignments from abroad, and will have to submit more SADs, collect and fill out more other kinds of permits and so on. But the issue is how these CCC

\footnotetext{
${ }^{17}$ For similar problems see Haughton's research (1998).

${ }^{18}$ Allers (1994) cites a number of researches of tax compliance costs that also obtained unrepresentative samples. Still, all those with unrepresentative samples did attempt to show that the costs of tax compliance were regressive.
} 
rise? Do they rise regressively? The CCC would rise regressively as compared with imports if for a $1 \%$ increase in the value of imports, CCC rise less than $1 \%$. It could be simply said that smaller small business pays more $\mathrm{CCC}$ comparing to their imports, than larger small business.

Table 1 shows that for the small businesses interviewed, there were indications of regressiveness. Thus conclusion is that the costs of CCC constitute a disproportionately greater burden for smaller small businesses.

Table 1 Regressiveness of CCC for small businesses in 2001

\begin{tabular}{|l|r|r|r|r|}
\hline $\begin{array}{l}\text { Value of the small business's } \\
\text { imports (in 000 of HRK) }\end{array}$ & $\mathbf{N}(\%)$ & $\begin{array}{r}\text { CCC } \\
\text { as \% of imports } \\
\text { (mean) }\end{array}$ & $\begin{array}{r}\text { CCC } \\
\text { per SAD } \\
\text { (mean in 000 HRK) }\end{array}$ & $\begin{array}{r}\text { CCC } \\
\text { per unit of duty paid } \\
\text { (mean) }\end{array}$ \\
\hline Up to 200 & 24 & 15.9 & 7.9 & 0.16 \\
\hline 200 to 300 & 35 & 9.2 & 3.2 & 0.09 \\
\hline More than 300 & 41 & 5.4 & 2.8 & 0.05 \\
\hline
\end{tabular}

* For each case CCC is expressed as a percentage of value of imports.

These percentages are then averaged within each size band. $N=$ size of the sample.

It is obvious that larger small businesses have relatively lower CCC. Thus the mean annual CCC in 2001 for small businesses who imported up to 200,000 HRK came to $16 \%$, while for small businesses that had imports over $300,000 \mathrm{HRK}$, they were about $5 \%$ of the value of their imports.

Table 1 shows that more SADs an importer submits, the smaller are his CCC per SAD. The mean CCC in 2001 for small businesses who imported up to 200,000 HRK came to about 8,000 HRK per SAD. It can thus be said that, on average, one import procedure for small business who imported up to 200,000 HRK costs roughly this much. ${ }^{19}$ For small businesses whose imports are greater than $300,000 \mathrm{HRK}$, the mean CCC were almost three times as little, or about 3,000 HRK per SAD.

Furthermore the more a small business's imports grow, the lower the CCC per unit of duty paid. The mean CCC in 2001 for small businesses who imported up to 200,000 HRK came to 16 lipa per each HRK of customs duty paid. For small businesses whose imports was greater than 300,000 the mean CCC were only 5 lipa for each HRK of duty paid.

Although it can be seen that there are indications of regressiveness, the calculations have shown that there are no statistically significant correlations between the $\mathrm{CCC}$ and the above mentioned variables. This is not surprising since it is a matter of a truly little sample. Hence the regressiveness shown in the preceding table can be presented only as an indicator of some possible confirmation of regressiveness in the CCC for small businesses, but with reservations, for nothing can be stated precisely without further researches.

\subsection{The results of the research with respect to legal entities}

The results from the legal entities interviewed were more useful. This is probably because an absolutely greater number of legal entities were interviewed than were small businesses. Thus after weighting a representative sample from the aspect of the quantities of imports for legal entities was

\footnotetext{
${ }^{19}$ We suppose that the importers were mainly importing and performing fewer of other types of customs procedures.
} 
obtained..$^{20}$ However, the sample for legal entities is not regionally representative. Thus because of lack of regional representativeness and because of the fact that the sample is very small, everything obtained by way of result of the analysis of our sample of legal entities is a depiction of the situation in the legal entities that import, and actually just an indication of what the situation might be like in the population of all the legal entities-importers in the RC. Or we can say that since the research of this kind have never been done in $\mathrm{RC}$, the results from this research can be used as rough indicators of possible real trends in the population.

The comprehensiveness of the sample of legal entities as compared with the total number of legal entities that are importers (the universe) is $0.271 \% .{ }^{21}$ Comparing the comprehensiveness of our sample with the comprehensiveness of the samples of some foreign researches of the costs of tax compliance, we should notice that our research covered a greater part of the universe than almost any other research. ${ }^{22}$

\subsubsection{The rise in the overall CCC with a rise in the imports of a legal entity}

The research confirmed the most logical expectation that as the imports of a legal entity rise, on average, the total (in the absolute amount) CCC also rise.

Table 2 Mean CCC according to the value of the imports of a legal entity in 2001

\begin{tabular}{|l|r|r|}
\hline $\begin{array}{l}\text { Value of the imports of a legal entity } \\
\text { (in 000 HRK) }\end{array}$ & N (\%) & CCC* (mean in 000 HRK) \\
\hline Up to 100 & 37 & 15 \\
\hline 100 to 500 & 26 & 20 \\
\hline 500 to 1000 & 10 & 24 \\
\hline 1000 to 5000 & 18 & 77 \\
\hline Over 5000 & 9 & 250 \\
\hline
\end{tabular}

*Mean costs for legal entities in this import bracket.

A legal entity that had imports up to 100,000 HRK spent about 15,000 HRK on average in 2001 for customs compliance, while a legal person with imports over 5 million HRK spent about 250,000 HRK.

So huge CCC for legal entities that had in 2001 imports of over 5 million HRK can partially be explained by the fact that two thirds of them paid the services of a agent on an ad valorem basis (or in pro mille of the value of the imports) (Appendix 2). Unluckily, the prices of agents' services are not statutorily regulated in the $\mathrm{RC}$.

\subsubsection{Regressiveness}

The regressiveness of the CCC was checked in comparison with size of imports, number of SADs and amount of duty paid. ${ }^{23}$

\footnotetext{
${ }^{20}$ Before weighting too many small legal entities and too little large legal entities were interviewed.

${ }^{21}$ The number of legal entities interviewed was 50, and the total number of legal entities-importers in 2001 was 18.422.

${ }^{22}$ For example, for the comprehensiveness of a sample with respect to total population for VAT and income tax of some other researchers, see Klun (2002).

${ }^{23}$ Since the distributions are not normal, the variables that are expressed in money are transformed with the use of a natural logarithm (In) which is a usual procedure when variables are at issue that are highly positively sloped (asymmetrically - spread out far to the right). After the transformation, the mean value is calculated, which is then transformed into a natural number.
} 
Table 3 The mean CCC according to value of imports of legal entities in 2001

\begin{tabular}{|c|c|c|c|c|c|}
\hline $\begin{array}{l}\text { Value of imports } \\
\text { (in } 000 \mathrm{HRK} \text { ) }\end{array}$ & N (\%) & $\begin{array}{r}\text { CCC } \\
\text { as \% of imports } \\
\text { (mean) * }\end{array}$ & $\begin{array}{r}\text { CCC } \\
\text { per employee } \\
\text { (mean in } 000 \text { HRK) }\end{array}$ & $\begin{array}{r}\text { CCC } \\
\text { per SAD } \\
\text { (mean in } 000 \text { HRK) }\end{array}$ & $\begin{array}{r}\text { CCC } \\
\text { per HRK of } \\
\text { customs paid } \\
\text { (mean) }\end{array}$ \\
\hline Up to 100 & 37 & 30.5 & 4.3 & 6.8 & 0.8 \\
\hline 100 to 500 & 26 & 9.9 & 3.5 & 2.6 & 0.3 \\
\hline 500 to 1000 & 10 & 4.0 & 3.0 & 1.0 & 0.5 \\
\hline 1000 to 5000 & 18 & 3.2 & 2.6 & 2.2 & 0.2 \\
\hline More than 5000 & 9 & 0.6 & 2.3 & 0.7 & 0.1 \\
\hline
\end{tabular}

${ }^{*}$ For each case CCC is expressed as a percentage of value of imports.

These percentages are then averaged within each size band.

It is established that the CCC are regressive and burden smaller legal entities to a disproportionately higher amount. Thus on average for legal persons with imports of below 100,000 HRK a year the annual CCC per employee in 2001 came to about 4,300 HRK, and for those whose imports were more than 5 million HRK, they came to only 2,300 per employee.

For legal persons who imported goods worth less than 100,000 HRK the mean annual CCC came to $30 \%$ of their imports, and for those who imported goods worth more than 5 million HRK a year they were almost fifty times smaller, that is, only $0.6 \%$ of their imports.

With a rise in the amount of the imports, the mean costs per SAD also fell, or we could say that the mean costs for one import procedure declined ${ }^{24}$. For legal entities with imports of less than 100,000 HRK, the mean costs per SAD came to about 7,000 HRK, and for those who imported goods worth more than 5 million HRK, these costs came to ten times as little, about 700 HRK per SAD.

As the imports of the legal entities rose, the CCC fell per unit of duty paid. Legal entities who imported goods to the value of less than 100,000 HRK paid 80 lipa for every HRK of customs duty paid, while entities that imported goods worth more than 5 million HRK paid only 10 lipa.

Thus it has been proved that the CCC of legal entities in the RC grow regressively, that is that the $\mathrm{CCC}$ are a relatively much greater burden on smaller legal entities, and thus the conclusion arises that it pays to import more.

\subsubsection{The total customs compliance costs for small businesses and legal entities in 2001}

The total CCC for legal entities and small businesses in 2001, were estimated by assuming that the mean costs for small businesses that are importers, depending on the magnitude of their imports, were approximately equivalent to the mean costs for legal entities with the same volume of imports. Thus we multiplied the arithmetical mean of the total CCC of legal entities for every size bracket of their import value (Table 2) by the number of small businesses and legal entities (importers) that have that value of imports. ${ }^{25}$

\footnotetext{
${ }^{24}$ It is usual for the importer to submit one SAD for each import.

${ }^{25}$ We obtained the number of legal entities and small business importers according to the volume of imports from the Customs Administration database. It should be mentioned that the number of small business importers from the Customs Administration database includes natural persons importers registered for small businesses and those registered for farming. It was not
} 
Table 4 The total CCC of all legal entities and small businesses according to value of imports in 2001

\begin{tabular}{|l|r|}
\hline Value of imports (in $\mathbf{0 0 0}$ HRK) & Total CCC (in million HRK) \\
\hline Up to 100 & 168 \\
\hline 100 to 500 & 128 \\
\hline 500 to 1000 & 55 \\
\hline 1000 to 5000 & 271 \\
\hline Over 5000 & 384 \\
\hline Total & $\mathbf{1 , 0 0 6}$ \\
\hline
\end{tabular}

The total CCC of all small businesses and legal entities in the RC in 2001 were estimated at 1,006 million HRK. How big are these as compared with GDP and total customs revenue in 2001 ?

Table 5 Estimated total CCC of small businesses and legal entities as percentage of GDP, the values of their imports and total customs revenue in 2001

\begin{tabular}{|l|r|}
\hline CCC & as \% of \\
\hline GDP in 2001 (current prices) & 0.6 \\
\hline total value of imports of small businesses and legal entities* & 1.7 \\
\hline total customs revenue in 2001 ** & 31.3 \\
\hline
\end{tabular}

*Source of values of imports of legal entities is the database of the Customs Administration.

${ }^{* *}$ Croatian National Bank, 2003.

Source: Finance Ministry, 2002a.

The total CCC of small businesses and legal entities in 2001 in the RC was estimated at $0.6 \%$ of GDP, $1.7 \%$ of the value of their imports, and about $31 \%$ of total customs revenue. From this estimate it follows that the total CCC for legal entities and small businesses are relatively large. Still, this estimate should be considered with a degree of caution, for as we have already stated it is possible that CCC are overstated.

We have mentioned many problems relating to the research. One of them is that although we attempted to exclude them from this research it is possible that the CCC do include costs related to matters such as transport, loading and unloading and so on, which are not CCC.

Then it is possible that some part of the costs relating to VAT and excise during the import procedure are included within the CCC. Finally, the Customs Administration database shows the number of small businesses (importers) together with the number of farmers (importers) without it being possible to distinguish the two. We assume that most of the importers are small businesses, but should mention that because farmers/importers are included in our calculation, the estimated CCC for small businesses and legal entities are bound to be estimated somewhat higher than they really are. In addition it is questionable if the figure about customs revenue collected in 2001 is correct. The Ministry of Finance and Croatian National Bank are not sure what the exact figure is because the figure about customs revenues collected is derived from an estimate. ${ }^{26}$

In addition Sandford (2000) states that the total CCC (in our case) can be lower than those shown in these calculations. The reasons are the monetary benefits for the taxpayer if the tax (in this case 
customs duty) is paid in arrears, and the spin-off benefits deriving from the easier running of the legal entity or small business with the assistance of the more exact and comprehensive records necessary for tax (customs) compliance. The said benefits are not considered in this paper, mostly because of the absence of data.

\subsubsection{Why are the costs of customs compliance so large?}

Firstly due to the coming into force of the new Customs Law and the entry into the WTO, customs revenues were smaller. Secondly, the same changes (the coming into force of the new Customs Law and the entry into the WTO) because of adaptation increased CCC for customs payers.

Thirdly we have already mentioned more than $50 \%$ of legal entities interviewed paid for the services of agents on an ad valorem basis (Annex 2). And this could result in very large amounts being paid to agents.

And then the question arises as to the point of the whole customs system, the customs laws, regulations, procedures and, ultimately, customs officials. Do they make customs compliance easier? Do they have an effect on the enlargement or diminution of the CCC? Hence in the interview the question was asked what persons who comply with customs consider the most complicated things, and what takes up the most time for them.

Table 6 Question: What in your opinion is the most complicated thing, and what takes up the most time in customs compliance?

\begin{tabular}{|l|r|r|r|}
\hline & $\mathbf{N}$ & \% & cum. \% \\
\hline Customs laws and regulations change too often & 20 & 40 & 40 \\
\hline $\begin{array}{l}\text { The decrees are inarticulate or illogical, and are implemented } \\
\text { according to the whims of the interpreter }\end{array}$ & 9 & 18 & 58 \\
\hline The customs procedure is untransparent and unpredictable & 1 & 2 & 60 \\
\hline The customs procedure is too long & 1 & 2 & 62 \\
\hline $\begin{array}{l}\text { The length of the procedure for phytosanitary, veterinarian and market } \\
\text { inspection }\end{array}$ & 0 & 0 & 62 \\
\hline Problems connected with customs personnel & 6 & 12 & 74 \\
\hline Miscellaneous & 4 & 8 & 82 \\
\hline Don't know / No answer & 9 & 18 & 100 \\
\hline Total & $\mathbf{5 0}$ & 100 & \\
\hline
\end{tabular}

The interviewees most often (40\%) said that the most complicated aspect or the thing that took up the most time in customs compliance was the frequent changing of customs laws and regulations. Secondly, decrees were inarticulate and illogical and were carried out according to the whims of those who were interpreting them (almost 20\%). Finally a relatively large number of interviewees (over 10\%) said that problems connected with customs personnel took the most time in customs compliance.

The question about what the interviewees would propose to make the whole of the customs procedure easier or to reduce CCC resulted in similar answers. On the whole the simplification of customs regulations and procedures was mentioned, as well as less frequent changing of the laws. 
The interviewees suggested a cutting of red tape, an acceleration of customs procedure, the computerisation of the CA and the need for highly qualified personnel with specialist knowledge, both among customs officers and agents. They also say that as many customs offices as possible should have the inspection services (phyto, veterinary and market), then that there is a need for better communication among customs offices, so that customs regulations should not be arbitrarily and wilfully interpreted. Finally, they state the need for strict and rigorous customs inspection, and more stringent penalties for infringements.

It is obvious that the interviewees were well initiated into the problems of their own job, and that they can provide many high-quality solutions. For this reason these persons should be contacted and consulted more often. But still, since some of the interviewees stated the need for a much simpler and accelerated customs procedure, the question arises of whether they use the actually existent simplified customs procedures to a sufficient extent.

Article 88 of the Customs Law does prescribe simplified procedures. Two kinds of simplified procedure are distinguished; 1. a simplified declaration on the basis of an invoice ${ }^{27}$ and 2. the exemption of the declarer for the need to submit the goods - the so-called privileged consignee and consignor ${ }^{28}$. In order to determine whether the legal entities interviewed did in fact make use of the opportunities of the privileged consignee or consignor, the questionnaire asked them a particular question.

Table 7 Question: Do you make use of the opportunities of privileged consignee or consignor?

\begin{tabular}{|l|r|r|}
\hline & $\mathbf{N}$ & \% \\
\hline Yes & 8 & 16 \\
\hline No & 39 & 78 \\
\hline Don't know / no answer & 3 & 6 \\
\hline Total & $\mathbf{5 0}$ & $\mathbf{1 0 0}$ \\
\hline
\end{tabular}

It is interesting that most of the legal entities interviewed (almost $80 \%$ ) did not make use of the opportunities of privileged consignee or consignor. A partial answer why this should be so can perhaps be seen from the following table.

\footnotetext{
${ }^{27}$ Simplified declaration on the basis of an invoice can be explained by the example of the importer of newspapers corporation $\mathrm{N}$ (dioničko društvo, d.d.) which every day and at several border crossings imports papers (daily newspapers, weeklies, monthlies...). If for all these papers the importer had to submit a SAD at every crossing every day, time and money would be wasted. Apart from that, if these papers have to be at the kiosks at say, 7 in the morning, there is no time to carry out all these procedures at the border (submission of SADs and so on) if the papers are to arrive on time. For this reason corporation $\mathrm{N}$ obtained permission to make use of the simplified declaration system on the basis of an invoice. Thus in practice, the truck comes to the customs house, the customs officers are submitted the invoice for the papers in the truck, and the customs officers at once let it pass. Once a week, corporation $\mathrm{N}$ submits to the Customs Administration a combined declaration including all these many invoices from the whole of the week and then, put simply, in this one declaration some 15 to 20 weekly consignments of papers are customs cleared.

${ }^{28}$ For example, pharmaceutical corporation $A$ is approved as privileged consignee. This means that goods from the border go directly to the warehouse of corporation A. There is thus no inspection of goods by the customs in the customs house or office (where goods are most often inspected and customs cleared). The user (corporation A) is obliged within a period of one hour of the arrival of the goods to inform the authorized customs house that the goods have arrived, and then the customs officer can in a period of half an hour from this come and inspect the goods, but does not have to. For example, goods arrive at the warehouse of corporation $A$ at 5 , corporation $A$ has to inform the customs administration of the arrival at the latest by 6 , and the customs administration can inspect the goods until 6.30. Until the administration officer arrives at 6.30 there is of course no removal of the customs marks from the truck (seals and so on) or unloading of goods. If the customs officers do not come to inspect the goods, they will inform the user, who can then take off the seals and unload the goods.
} 
Table 8 Does making use of the opportunities of privileged consignee or consignor make the customs clearing procedure easier?

\begin{tabular}{|l|r|r|}
\hline & $\mathbf{N}$ & $\%$ \\
\hline Yes & 3 & 37 \\
\hline No & 5 & 63 \\
\hline Total & $\mathbf{8}$ & 100 \\
\hline
\end{tabular}

Two thirds of those interviewed who did make use of the opportunities of the status of privileged consignee/consignor on the whole $(63 \%)$ state that this did not make the customs procedure any easier for them. It is possible that the interviewees did not make use of this opportunity because it requires a lot of care and responsibility. For example privileged consignees/consignors have to keep bookkeeping records in which they must enter all data about the arrival and departure of goods, the tariff numbers, the weight and so on. And it is important to note that privileged consignees/consignors themselves authenticate SADs, with the assistance of a seal that they obtain from the Customs Administration.

Since the importers interviewed stated that for any simplification of the customs procedure and a reduction in the CCC, greater computerisation is necessary, the question was asked of whether they did at the moment use the existing possibilities for submitting SADs by Internet.

For according to Article 71 of the Croatian Customs Law, all goods that are put into the customs procedure must have SADs submitted for them. The SAD is submitted in writing, on-line (if there is the technology for it, and if it is approved by the CA), orally, and in some other procedures ${ }^{29}$ by which the owner of the goods requests that the goods be entered into the customs procedure.

Table 9 Question: Do you make use of the possibility of submitting SAD via the Internet?

\begin{tabular}{|l|r|r|}
\hline & $\mathbf{N}$ & $\%$ \\
\hline Yes & 17 & 35 \\
\hline No & 31 & 65 \\
\hline Total & $\mathbf{4 8}$ & $\mathbf{1 0 0}$ \\
\hline
\end{tabular}

Only $35 \%$ of importers use on-line system for submitting their SADs. One of the reasons must be the generally inadequate use of the Internet in the RC. Thus CIA (2003) estimates that in Croatia in 2001 about 480.000 or about $10 \%$ of the population used the Internet. However, perhaps this is not the only reason for the relatively small number of importers that submit their SADs via the Internet, and so this should be explored further in the future, particularly since the responses to the following question show that those importers that did submit their SADs via the Internet found it largely simplified the customs procedure.

\footnotetext{
${ }^{29}$ Declaration by other actions is explained in Articles 102-107 of the Decree for Implementation of the Customs Law, for example, the use of the green "nothing to declare" line.
} 
Table 10 Question: Has submitting SADs via the Internet simplified the customs procedure?

\begin{tabular}{|l|r|r|}
\hline & $\mathbf{N}$ & $\%$ \\
\hline Yes & 14 & 82 \\
\hline No & 3 & 18 \\
\hline Total & 17 & 100 \\
\hline
\end{tabular}

It would seem that the submission of the SAD via the Internet in about $80 \%$ of cases simplified the customs procedure. Hence the recommendation for all importers is that they should certainly use this possibility more.

Apart from the questions asked to date, using the Likert test scale of five points there was an attempt to get more precise information about the satisfaction of the interviewees with the work of the officials of the CA (Allers, 1994).

Table 11 Question: On a scale of 1 to 5 please estimate your degree of satisfaction with the work of the Customs officials.

\begin{tabular}{|l|r|r|r|}
\hline & $\mathbf{N}$ & $\mathbf{\%}$ & cum. \% \\
\hline Not satisfied & 5 & 10 & 10 \\
\hline Partially satisfied & 1 & 2 & 12 \\
\hline Satisfied & 23 & 46 & 58 \\
\hline Very satisfied & 8 & 16 & 74 \\
\hline Exceptionally satisfied & 3 & 6 & 80 \\
\hline Don't know / No answer & 10 & 20 & 100 \\
\hline
\end{tabular}

Around $10 \%$ of respondents answered that they were not satisfied with the work of the Customs officials. Still, we can conclude that the interviewees were on the whole satisfied with the work of the officials of the Customs officials, because around $70 \%$ gave it a grade of from 3 to 5 .

The most common grade, 3, average (satisfied with the work of the officials of the Customs Administration) is very likely a reflection of behaviour and work at the customs offices that are not always homogenous. Thus the interviewees said that some customs officers wanted to help, others did not. A certain number of those interviewed complained of the slow procedure, the long waiting, the pettiness and complications at some customs offices, the diversity of interpretation of regulations, the poor availability of information, the inaccessibility and arrogance of some officers.

On the other hand many say that they are mainly satisfied with the services provided by the customs personnel and that sometimes the personnel are not to be blamed for their procedures because they are not informed, not well enough trained for the jobs they do, not independent, and are part of a CA that is in itself complicated. Thus it is up to the CA, on its own or with the help of the importers, to discover which employees and where should and could improve their work, and in this manner attempt to simplify and speed up the customs procedure and reduce CCC

Researches of the costs of tax compliance often mention the so-called psychological cost. Here we have defined this as the unease that arises when filling out and submitting SADs. 
Table 12 Question: How do you feel after your SAD has been received in the CA?

\begin{tabular}{|l|r|r|}
\hline & N & $\%$ \\
\hline Disturbed, because of the great tension & 2 & 4 \\
\hline Relieved, because I have finished a big job & 14 & 28 \\
\hline Pleased, because I was able to do everything easily & 4 & 8 \\
\hline Pleased, because I did it all & 9 & 10 \\
\hline Indifferent & 2 & 20 \\
\hline Something else & 9 & 4 \\
\hline Don't know / No answer & $\mathbf{5 0}$ & 18 \\
\hline Total & $\mathbf{1 0 0}$ \\
\hline
\end{tabular}

The large number of don't knows (18\%) shows that the respondents either did not understand the question well, or did not know how to answer it. In general it can be seen that there is a certain psychological cost, because $4 \%$ of the interviewees replied that they felt agitated or disturbed because of the great tension, and the highest number of importers, almost $28 \%$, replied that they felt relieved, because they had done a big job.

We now introduce the opinion of the interviewees about whether the CCC have increased or decreased in the last five years.

7.2.5. The opinion of the interviewees about changes in the amount of the CCC in the last five years.

Table 13 Question: Do you think that the CCC have increased or decreased in the last five years?

\begin{tabular}{|l|r|r|}
\hline & $\mathbf{N}$ & $\%$ \\
\hline Increased & 17 & 34 \\
\hline Decreased & 22 & 44 \\
\hline Don't know / No answer & 11 & 22 \\
\hline Total & $\mathbf{5 0}$ & $\mathbf{1 0 0}$ \\
\hline
\end{tabular}

Although major changes happened in the customs system of the RC in 2000, in this question the opinion of the interviewees about changes in the amount of CCC in the last five years, because we were endeavouring to determine some long-term trend in the CCC.

About $30 \%$ of the interviewees replied that the CCC had increased in the past five years. They state that revenue stamps, fees and forms had increased, and that because of the complication of the law, it was more necessary to keep up with the literature and seminars, and that there was still too much paperwork connected with the business.

Nevertheless, the majority of the interviewees, about $40 \%$, answered that they thought the CCC had diminished in the last five years. They adduced as reasons the fall in the prices of the services of agents, the abolition of tariffs for some goods and so on. Finally, in next section, recommendations on how to reduce $\mathrm{CCC}$ and recommendations for the future researchers of $\mathrm{CCC}$ will be given. 


\section{RECOMMENDATIONS}

\subsection{Recommendations to the Customs Administration}

The purpose of investigating the CCC in the RC was to try to calculate the amount of CCC in RC in 2001 for importers (legal entities and small businesses) and then to suggest how to reduce these costs. The research showed that customs payers had the greatest problems with the frequent modification of customs laws and regulations. Secondly customs ordinances were inarticulate and illogical and were carried out according to the whims of those who were interpreting them. Thus for the reduction of CCC it is important that the customs system and legislation are simple, clear and unambiguous, as well as lasting and predictable.

It is necessary to realise that we are living in the information era when data can be transferred quickly, cheaply and securely by electronic media. Even in this research $80 \%$ of the informants stated that the submission of the SAD online simplified the customs procedure for them. Thus it is essential to encourage the submission of the SAD online, and improve the accessibility of customs information via electronic means, so that all information related to customs laws, regulations, procedures and the practice of the customs administration should be accessible to all participants as soon as possible. ${ }^{30}$ It is necessary to develop a Customs information system compatible with similar systems in the countries of EU, from the points of view of hardware, software and telecommunications. The basis for such an information system should be the Automatic System for Customs Data (ASYCUDA) developed by UNCTAD, broadly accepted worldwide (Galinec and Jurlin, 2002).

The level of technical and staff preparedness at customs crossings should be raised to a higher level in order to cut the time vehicles spend waiting at the border crossings for the customs procedure. For the present the number of international border crossings at which there is a veterinary and phytosanitary department is limited, and the working hours of these departments is short, which means long waits for customs, all of which increases the operating costs of haulage firms. Thus there should be as many highly specialised and qualified customs officers and agents as possible, and more customs houses should have inspection departments (phyto, veterinary, market and so on) so as to speed up the customs procedure. The education of customs employees can be carried out by having them involved in EU customs employee training programs (such as the MATTHEUS program) (Galinec and Jurlin, 2002). Furthermore the crossings must also be furnished with contemporary equipment for the purpose of customs control of agricultural products, the use of which is entailed by the provisions of the CAP.

From all this, it can be seen that the Customs Administration still has to cope with the not very simple tasks of updating its computerisation, simplifying its procedures and expert team-building. Also necessary is improvement of the technical equipment of the customs crossings. The Customs Administration, with the help of a World Bank loan, has already started working on some of these

\footnotetext{
${ }^{30}$ Praiseworthy indeed is the existence of the Web site of the CA, with a number of useful and interesting data; see http://www.carina.hr. But far more data could be put on this Web site.
} 
projects as part of the "Trade and Transport Facilitation in Southeast Europe" project (Kovačević, 2002).

As well as this, it should be pointed out that it is necessary to have in society as a whole further democratisation, advances in law and order, more transparent public finances which would certainly lead to reductions in the CCC.

\subsection{Recommendations to importers}

After this statement of what the CA should do to reduce the CCC, the question arises: what could and should importers do to reduce their own costs? Since we have shown that the CCC are a disproportionately greater burden on legal entities that import less, importers should do their best to import as much as possible. They should also make use of existing opportunities for simplified customs clearing and use the advanced communications technology more.

\subsection{Recommendations to researchers in the area of the CCC}

Now follow a series of recommendations to researchers in the domain of CCC. Firstly, because of the series of conceptual and methodological problems that research encounters at the very outset, it is necessary to know the existing literature concerning the costs of tax or customs compliance, and also to consult people with practical knowledge who deal with the customs procedure every day, in order to be able precisely to define what can be investigated and who should be asked.

The number of hypotheses to be tested should be restricted. This research endeavoured to test too many hypotheses, and the questionnaire turned out to be too long and too complicated. This ultimately had a negative effect on the representativeness of one of the samples.

If a large population is to be investigated it would seem to be best to keep the questions quite simple and easier for the interviewees to answer.

It would be good to reduce the number of people needing to be interviewed in order to fill in a single questionnaire. Because of the large number of people needing to be interviewed (as many as three sometimes) for the completion of a single questionnaire in this research it was not possible to interview enough people. This ultimately led to the small businesses sample being unrepresentative and the data collected being impossible to analyse in any detail.

In any subsequent research it would be best for the researchers themselves to carry out the pilot projects. In this way they would be sure which questions are unclear for the interviewees and what needs changing so the questionnaire should be as intelligible and acceptable as possible to them. 


\section{Conclusion}

The CCC (even if they are very small) result in a diminution of international trade. Since it is frequently said that international trade increases employment, economic growth and thus leads to a better standard of living, the objective of each state should be to reduce the CCC.

Because of these and some other reasons mentioned in this research the CCC in Croatia in 2001 were investigated. The results of the research need to be considered with caution, in particular because research of this kind has never been carried out in the Republic of Croatia; because there was not much literature concerning CCC; and because CCC were hard to identify and measure.

The most important results of the research show that the CCC in the RC in 2001 were large. It is estimated that in 2001 they came, for all Croatian importers (legal entities and small businesses combined), to 1,006 million HRK. This is $0.6 \%$ of GDP, $1.7 \%$ of the value of all their imports, and is equivalent to $31 \%$ of total customs revenue collected. It has been pointed that the $\mathrm{CCC}$ are regressive for both legal entities and small businesses, that is, that smaller legal entities and small businesses have disproportionately greater CCC.

There is not, unfortunately, a single foreign research of the CCC that could be used as a comparison. For this reason we would conclude that the primary purpose of this research is that it should help us to pose the relevant questions related to the size and characteristics of the $\mathrm{CCC}$ and to help us conclude how CCC could be reduced. 


\section{Literature}

Allers, M. 1994, Administrative and Compliance Costs of Taxation and Public Transfers in the Netherlands, Groningen, Rijksuniversiteit Groningen.

Buršić, N., F. Ibrišimović and Zuber, M. 2002, «Djed Mraz na udaru hrvatskih carinika», Poslovni tjednik,42, 10-12.

Bratić, V. and Pitarević, M. 2003, "Administrativni troškovi oporezivanja i carinjenja u RH, 1999 2001". In Troškovi oporezivanja u Hrvatskoj: administrativni troškovi i troškovi ispunjavanja porezne obveze (u pripremi). Zagreb: Institut za javne financije.

Carinski zakon, NN 78/99, 94/99, 117/99, 73/00 i 92/01. Zagreb: Narodne novine.

Central Intelligence Agency, 2003. The World Factbook 2002. - Internet users [on line]. Available from: http://www.cia.gov/cia/publications/factbook/fields/2153.html

Croatian national bank, 2003. Bulletin Number 83. Zagreb: Croatian National Bank.

Ekonomski leksikon. 1995, Zvonimir Baletić (editor), Zagreb, Leksikografski zavod Miroslav Krleža, Masmedia.

Galinec, D. 2001, «Robna razmjena Republike Hrvatske tijekom 2000. godine», Carinski vjesnik 5, 46-54.

Galinec, D. and Jurlin, K. 2002, «Liberalizacija trgovinskog režima RH i reforma carinskog sustava», Carinski vjesnik 10, 3-13.

Haughton, J. 1998, «Measuring the Compliance Costs of Excise Taxation», African Economic Policy, Discussion Paper Number 14 [online]. Available from: http://www.eagerproject.com/discussion14.shtml

Kesner-Škreb, M. 1999, «Ukupni troškovi ubiranja poreza», Financijska teorija i praksa 2, 202-207.

Kesner-Škreb, M. and Kuliš, D. 2001, Porezni vodič za građane, Zagreb, Institut za javne financije.

Klun, M. 2002, «Troškovi ispunjavanja porezne obveze u Sloveniji», Financijska teorija i praksa 4, 775-793.

Kovačević, V. 2002, «Pilot lokacije: test reforme i racionalizacije Carinske uprave (I)», Carinski vjesnik 10, 13-24.

Kovačević, V. 2002a, «Pilot lokacije: test reforme i racionalizacije Carinske uprave (II)», Carinski vjesnik 11, 37-51.

Narodne novine, different issues. Zagreb: Narodne novine.

Ministarstvo financija, 2003, Republika Hrvatska, ukupno ostvarenje prihoda i izvršenje rashoda proračuna [online], Zagreb, Ministarstvo financija. Available from: http://www.mfin.hr/lokalna/2001/hrvatska.htm

Ministarstvo financija, 2003a, Mjesečni statistički prikaz Ministarstva financija, 81. Zagreb: Ministarstvo financija.

Ott, K. and Bajo, A. 2000, «Troškovi oporezivanja u tranzicijskim zemljama: iskustvo Hrvatske», Financijska teorija i praksa 2, 169-188.

Rutherford, D. 1995, Routledge Dictionary of Economics, London, New York, Routlege.

Sandford, C., Godwin, M. and Hardwick, P. 1989, Administrative and compliance costs of taxation, Bath, Fiscal Publications.

Sandford, C. 2000, Why tax system differ: A comparative study of the political economy of taxation, Bath, Fiscal Publications.

Verwaal, E. and Donkers, B. 2001, «Customs-Related Transaction Costs, Firm Size and International Trade Intensity», ERIM Report Series Research in Menagement ERS-2001-13MKT [online]. Available from: http://www.eur.nl/WebDOC/doc/erim/erimrs20010226105731.pdf 
Verwaal, E. and Cnossen, S. 2002, Europe's New Border Taxes [online]. Available from: http://www.few.eur.nl/few/research/pubs/ocfeb/documents/rm0008.pdf

World Customs Organization. 2003, Customs world renews its attack on the level of costs to international trade [online]. Available from: http://www.wcoomd.org/ie/En/Press/press.html

Zakon o carinskoj tarifi, NN 61/00 i 117/00. Zagreb: Narodne novine. 


\section{Annex 1.}

The structure of legal entities and small businesses interviewed according to geographical area

Small businesses

\begin{tabular}{|l|r|r|}
\hline Settlement & N & \% \\
\hline Zagreb & 4 & 24 \\
\hline Split & 6 & 35 \\
\hline Varaždin & 6 & 35 \\
\hline Velika Ves & 1 & 6 \\
\hline Total & $\mathbf{1 7}$ & $\mathbf{1 0 0}$ \\
\hline
\end{tabular}

Legal entities

\begin{tabular}{|l|r|r|}
\hline Settlement & $\mathbf{N}$ & \% \\
\hline Zagreb & 32 & 64 \\
\hline Split & 4 & 28 \\
\hline Varaždin & 4 & 8 \\
\hline Total & $\mathbf{5 0}$ & $\mathbf{1 0 0}$ \\
\hline
\end{tabular}

\section{Annex 2.}

Relationship between the amount of the imports of a legal entity and the payment contract it had with agents for customs compliance (in \%)

\begin{tabular}{|l|r|r|r|r|r|r|}
\hline $\begin{array}{l}\text { Value of imports } \\
\text { in 2001 (in 000 } \\
\text { HRK) }\end{array}$ & $\begin{array}{r}\text { Fixed price } \\
\text { for each } \\
\text { SAD }\end{array}$ & $\begin{array}{r}\text { According to a } \\
\text { minimum and } \\
\text { maximum } \\
\text { fixed price }\end{array}$ & $\begin{array}{r}\text { Ad valorem } \\
\text { (in per mille of } \\
\text { the value of the } \\
\text { imports) }\end{array}$ & $\begin{array}{r}\text { Some } \\
\text { other } \\
\text { way }\end{array}$ & $\begin{array}{r}\text { Don't } \\
\text { know/No } \\
\text { answer }\end{array}$ & Total \\
\hline Up to 100 & 50 & & 50 & & & 100 \\
\hline 100 to 500 & 30 & & 30 & 20 & 20 & 100 \\
\hline 500 to 1000 & & 25 & 75 & & & 100 \\
\hline 1000 to 5000 & 22 & & 78 & & & 100 \\
\hline over 5000 & 33 & & 67 & & & 100 \\
\hline Total & $\mathbf{3 4}$ & $\mathbf{2}$ & $\mathbf{5 4}$ & $\mathbf{5}$ & $\mathbf{5}$ & $\mathbf{1 0 0}$ \\
\hline
\end{tabular}

\section{Annex 3.}

The structure of legal entities interviewed according to the value of their imports

\begin{tabular}{|c|c|c|c|c|}
\hline $\begin{array}{l}\text { Value of imports in } 2001 \\
\text { (in } 000 \text { HRK) }\end{array}$ & $\begin{array}{l}\text { Number in } \\
\text { population }\end{array}$ & $\%$ population & $\begin{array}{r}\text { Number in } \\
\text { sample }\end{array}$ & $\%$ sample \\
\hline Up to100 & 6,823 & 37 & 4 & 8 \\
\hline 100 to 500 & 4,737 & 26 & 8 & 16 \\
\hline 500 to 1000 & 2,018 & 11 & 10 & 20 \\
\hline 1000 to 5000 & 3,320 & 18 & 10 & 20 \\
\hline Over 5000 & 1,524 & 8 & 18 & 36 \\
\hline Total & 18,422 & 100 & 50 & 100 \\
\hline
\end{tabular}




\section{INSTITUTE OF PUBLIC FINANCE - OCCASIONAL PAPER SERIES}

No. 1 State Intervention for Growth Promotion in Market Economies

Marina Kesner Škreb, January 1997

No. 2 Estimate of Revenues from the Value Added Tax in the Republic of Croatia

Danijela Kuliš and Žarko Miljenović, October 1997

No. 3 The Unofficial Economy in Croatia: Causes, Size and Consequences

Ivo Bićanić and Katarina Ott, November 1997

No. 4 Price Effects of VAT Introduction in Croatia

Martina Dalić, December 1997

No. 5 Tax Administration Reform in Transition: The Case of Croatia

Katarina Ott, April 1998

No. 6 The Present Sate of the Croatian Public Debt

Zoran Bubaš, December 1998

No. 7 Public Investment in Croatia

Katarina Ott and Anto Bajo, March 1999.

No. 8 Welfare Policy and Social Transfers in Croatia

Predrag Bejaković and Alastair McAuley, July 1999

No. 9 Is Unofficial Economy a Source of Corruption?

Vedran Šošić and Michael Faulend, November 1999

No. 10 Banking Sector Problems: Causes, Resolutions and Consequences

Ljubinko Jankov, March 2000

No. 11 Toward a Long - Term Strategy of Economic Development of Croatia: Where to Begin, What to Do, and How to Do It?

Dubravko Mihaljek, June 2001

No. 12 The Underground Economy in Croatia

Katarina Ott, March 2002

No. 13 An Estimate of the Extent of Tax Evasion in Croatia

Sanja Madžarević Šujster, April 2002

No. 14 Opportunism, Institutions and Moral Costs: The Socio - Cultural Dimension of the Underground Economy in Croatia 1995 - 1999

Aleksandar Štulhofer and Ivan Rimac, April 2002 
No. 15 Dollarisation and the Underground Economy: Accidental Partners?

Vedran Šošić and Michael Faulend, April 2002

No. 16 Decentralization in the Republic of Croatia - A City Budget in the Period from 1996 to 2000

Mihaela Pitarević, March 2003

No. 17 Inequality in Croatia in the Period from 1973 to 1998

Danijeli Nestić, April 2003

No. 18 State Aid to Enterprises in Croatia in 2001

Marina Kesner-Škreb, Ivana Pleše and Mia Mikić, October 2003

No. 19 The Role of Parliament in the Budgetary Process - The Example of the Croatian Parliament (2000-2003)

Vjekoslav Bratić, October 2004

No. 20 Local Government Unit Borrowing in Croatia: Opportunities and Constraints Anto Bajo, October 2004

No. 21 The costs of customs compliance in Croatia in 2001

Mihaela Bronić, November 2004 